WSRC-TR-2002-00238

\title{
Alternative HEPA Filter Full-scale Single Element Testing
}

\author{
Author: Duane J . Adamson
}

September, 2002

Westinghouse Savannah River Company Savannah River Technology Center Aiken, SC 29808

Prepared for the U.S. Department of Energy under Contract DE-AC09-96SR18500 
This document was prepared in conjunction with work accomplished under Contract No. DE-AC09-96SR18500 with the U. S. Department of Energy.

\section{DISCLAIMER}

This report was prepared as an account of work sponsored by an agency of the United States Government. Neither the United States Government nor any agency thereof, nor any of their employees, makes any warranty, express or implied, or assumes any legal liability or responsibility for the accuracy, completeness, or usefulness of any information, apparatus, product or process disclosed, or represents that its use would not infringe privately owned rights. Reference herein to any specific commercial product, process or service by trade name, trademark, manufacturer, or otherwise does not necessarily constitute or imply its endorsement, recommendation, or favoring by the United States Government or any agency thereof. The views and opinions of authors expressed herein do not necessarily state or reflect those of the United States Government or any agency thereof.

This report has been reproduced directly from the best available copy.

Available for sale to the public, in paper, from: U.S. Department of Commerce, National Technical Information Service, 5285 Port Royal Road, Springfield, VA 22161, phone: (800) 553-6847, fax: (703) 605-6900

email: orders@ntis.fedworld.gov

online ordering: http://www.ntis.gov/help/index.asp

Available electronically at http://www.osti.gov/bridge

Available for a processing fee to U.S. Department of Energy and its contractors, in paper, from: U.S. Department of Energy, Office of Scientific and Technical Information, P.O. Box 62, Oak Ridge, TN 37831-0062,

phone: (865)576-8401,

fax: (865)576-5728

email: $\underline{\text { reports@ adonis.osti.gov }}$ 
WSRC-TR-2002-00238

KEYWORDS:

HEPA Filter

Ceramic

Sintered metal

Regenerative In situ

Cleanable Filter

Retention: Permanent

\title{
Alternative HEPA Filter Full-scale Single Element Testing (U)
}

\author{
By
}

D. J. Adamson

Duars f. Udambere

ISSUED: September 2002

SRTC SAVANNAH RIVER TECHNOLOGY CENTER, AIKEN, SC 29808

Westinghouse Savannah River Company

Prepared for the U.S. Department of Energy under

Contract DE-AC09-96SR 18500 
Document: WSRC-TR-2002-00238

Title: Alternative HEPA Filter Full-scale Single Element Testing (U)

Approvals

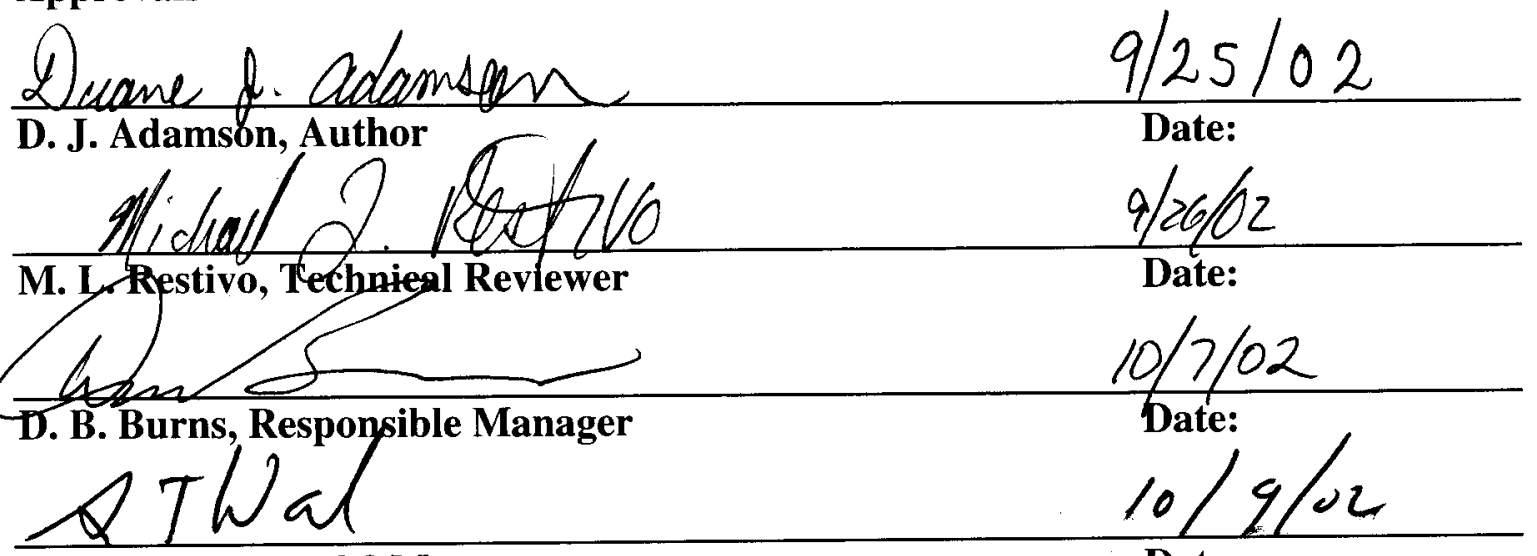

S. T. Watch, Level 3 Manager

Date:

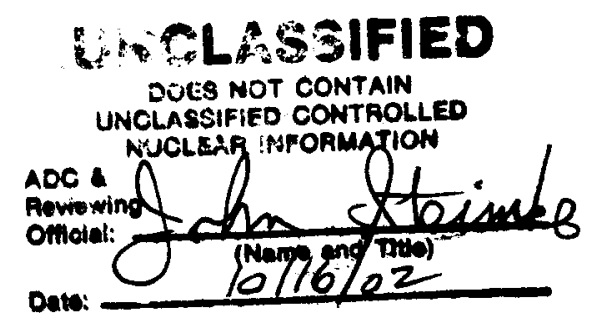


Report Revision Number $\quad 0$

Report Number: WSRC-TR-2002-00238

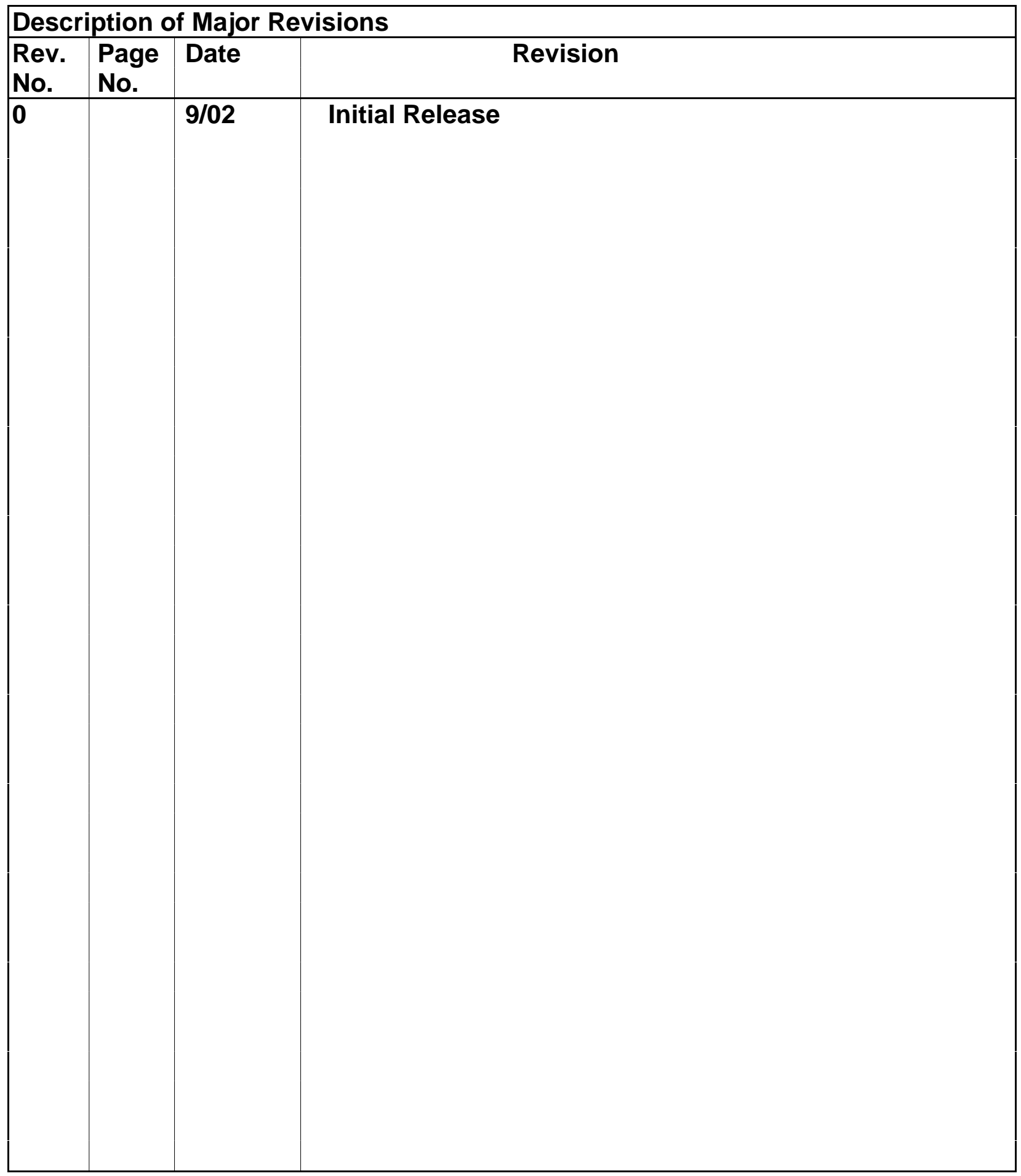




\section{EXECUTIVE SUMMARY}

Savannah River Technology Center (SRTC), High Level Waste (HLW) Division, Tanks Focus Area (TFA), and the National Energy Technology Laboratory (NETL) have investigated two types of full-scale filter elements, ceramic and sintered metal, for possible deployment as in situ regenerable/cleanable High Efficiency Particulate Air (HEPA) filters. The filters were investigated to replace conventional glass-fiber HEPA filters on high level-waste tanks. Conventional HEPA filters require frequent removal, replacement, and disposal. This is not only costly and subjects site personnel to radiation exposure, but adds to the ever-growing waste disposal problem.

Particle retention testing was conducted on the full-scale filter elements at the Oak Ridge Filter Test Facility with positive results, proving that the ceramic and sintered metal full-scale filters could be manufactured to the HEPA retention requirements. The filters had particle retention efficiency $\geq 99.97 \%$ when challenged with industrial standard, $0.3-\mu \mathrm{m}$ di-octyl phthalate (DOP).

At SRTC the full-scale filter elements were subjected to an environment that simulated conditions that challenge the high-level waste tank ventilation systems. The test apparatus was designed to promote rapid filter plugging to maximize the number of filter loading/cleaning cycles that would occur in a specified period of time. The filters were challenged using non-radioactive simulated high-level waste materials and atmospheric dust. After plugging the filters, they were cleaned in situ using aqueous solutions. The study found that both filter media were insensitive to high humidity or moisture conditions. The filters regenerated well even after numerous plugging and in situ cleaning cycles. However for the overall test campaign, the filters did not return to a clean filter status that was witnessed in the small scale filter testing. This may be due to the hostile test conditions and/or the cleaning method not optimized for the full-scale elements.

The sintered metal and ceramic filters not only can be cleaned in situ, but also hold great potential as a long life alternative to conventional HEPA filters. The structurally stronger sintered metal and ceramic filters would reduce the potential of a catastrophic HEPA filter failure due to filter media breakthrough in the process ventilation system. An in situ regenerable HEPA filter system may also have many other applications across the DOE complex as well as commercially.

Through the Tanks Focus area, this technology was shared with other locations such Idaho National Engineering Laboratory, West Valley and Lawrence Livermore National Laboratory with positive results. 


\section{ACKNOWLEDGMENTS}

Many thanks to those individuals who supported this task:

The Department of Energy's Office of Science and Technology and particularly the Tanks Focus Area (TFA) without whose technical and fiscal support this work could not have been conducted. Special gratitude is also extended to the National Energy Technology Laboratory for having provided the valuable contracting support.

To the vendors, CeraMem Corporation and Mott Corporation for their expertise and dedication to the alternative filtration technology.

D. W. Crosby and J. A. Davis of Air Techniques International for their expertise in HEPA filter testing and for conducting the particle retention testing at the Oak Ridge Filter Test Facility.

J. E. Mills, V. L. Bush and M. L. Armstrong for their dedication in modifying the HEPA filter test apparatus (HFTA), calibrating instruments, and fine tuning the HFTA in the Engineering Development Laboratory. 


\section{TABLE OF CONTENTS}

\begin{tabular}{|c|c|c|}
\hline \multicolumn{3}{|l|}{ Page } \\
\hline \multicolumn{2}{|c|}{ Executive Summary } & 1 \\
\hline \multicolumn{2}{|c|}{ Acknowledgments } & 2 \\
\hline \multicolumn{2}{|c|}{ Table of Contents } & 3 \\
\hline \multicolumn{2}{|c|}{ Background } & 4 \\
\hline \multicolumn{2}{|c|}{ Typical HLW Tank Ventilation System Flow Diagram } & 5 \\
\hline \multicolumn{2}{|c|}{ Introduction } & 6 \\
\hline \multicolumn{2}{|c|}{ Ceramic Full-scale Filter Element Photo } & 7 \\
\hline \multicolumn{2}{|c|}{ Ceramic Filter Flow Path } & 8 \\
\hline \multicolumn{2}{|c|}{ Ceramic Media Micrograph } & 8 \\
\hline \multicolumn{2}{|c|}{ Sintered Metal Full-scale Filter Element Photo } & 9 \\
\hline \multicolumn{2}{|c|}{ Sintered Metal Media Micrograph } & 10 \\
\hline \multicolumn{2}{|c|}{ Test Loop Description } & 10 \\
\hline \multicolumn{2}{|c|}{ Picture of HFTA } & 11 \\
\hline \multicolumn{2}{|c|}{ Schematic of HFTA } & 12 \\
\hline \multicolumn{2}{|c|}{ Instrumentation } & 13 \\
\hline \multicolumn{2}{|c|}{ Results and Discussion } & 14 \\
\hline \multicolumn{2}{|c|}{ Conclusions } & 16 \\
\hline \multicolumn{2}{|l|}{ References } & 17 \\
\hline Appendix A: & Particle Retention Test Results & 18 \\
\hline Table 1: & Ceramic Full-scale Filters & 19 \\
\hline Table 2: & Sintered Metal Full-scale Filters & 21 \\
\hline Appendix B: & List of cleaning curves & 23 \\
\hline Curve 1: & Sludge Solution, dP across CeraMem Filter & 24 \\
\hline Curve 2: & Sludge Solution, dP across Mott Filter & 25 \\
\hline Curve 3: & Salt Solution, dP across CeraMem Filter & 26 \\
\hline Curve 4: & Salt Solution, dP across Mott Filter & 27 \\
\hline Curve 5: & SC Road Dust, dP across CeraMem Filter & 28 \\
\hline Curve 6: & SC Road Dust, dP across Mott Filter & 29 \\
\hline
\end{tabular}




\section{BACKGROUND}

Conventional disposable glass-fiber high efficiency particulate air (HEPA) filters are used throughout the Department of Energy (DOE) complex in various process systems. The filters must exhibit a particle removal efficiency of $99.97 \%$ when challenged by thermally generated di-octyl phthalate (DOP) aerosol with a diameter of 0.3 microns. The pleated glass fiber HEPA filter media has approximately $240 \mathrm{ft}^{2}$ of surface area and is typically contained in a $2 \mathrm{ft}$. $2 \mathrm{ft} x 1 \mathrm{ft}$. housing and exhibits a 1 inch of water column (wc) differential pressure across the filter media when clean. On High Level Waste (HLW) tanks at the Savannah River Site (SRS), a conventional HEPA filter remains in service until the filter media reaches a predetermined maximum pressure drop (approximately 5 inches) or a high source term due to buildup of radioactive material, and then the filter is replaced. These filters require routine removal, replacement, and disposal. This process is not only expensive, but also subjects personnel to radiation exposure and adds to an ever-growing waste disposal problem. These concerns are what generated the need statement (SR012027) for finding alternative filter media that would have a long life on the HLW tanks.

The conventional HEPA filters also have safety concerns in the areas of filter media strength, water damage, and operation in environments with elevated temperatures. In 1999 the Defense Nuclear Facility Safety Board issued a report titled "HEPA Filters used in the Department of Energy Hazardous Facilities", DNFSB/TECH-23 that documents these and other concerns pertaining to conventional HEPA filters. ${ }^{(1)}$

Figure 1 depicts a typical ventilation system on a HLW tank at SRS. The tanks are designed to hold approximately 1.0 million gallons of radioactive liquid waste. The tanks are located mostly underground and outdoors. The tanks are equipped with a ventilation system to maintain the tank contents at negative pressure (approximately 1.0" water column). The negative pressure prevents the release of radioactive material to the environment but also allows for atmospheric dust to be pulled into the tank during certain maintenance activities. The inlet air, approximately $500 \mathrm{cfm}$, is filtered before entering the headspace of the tank. The airflow aids in tank cooling and purging out gases that may form from the waste such as Hydrogen. 


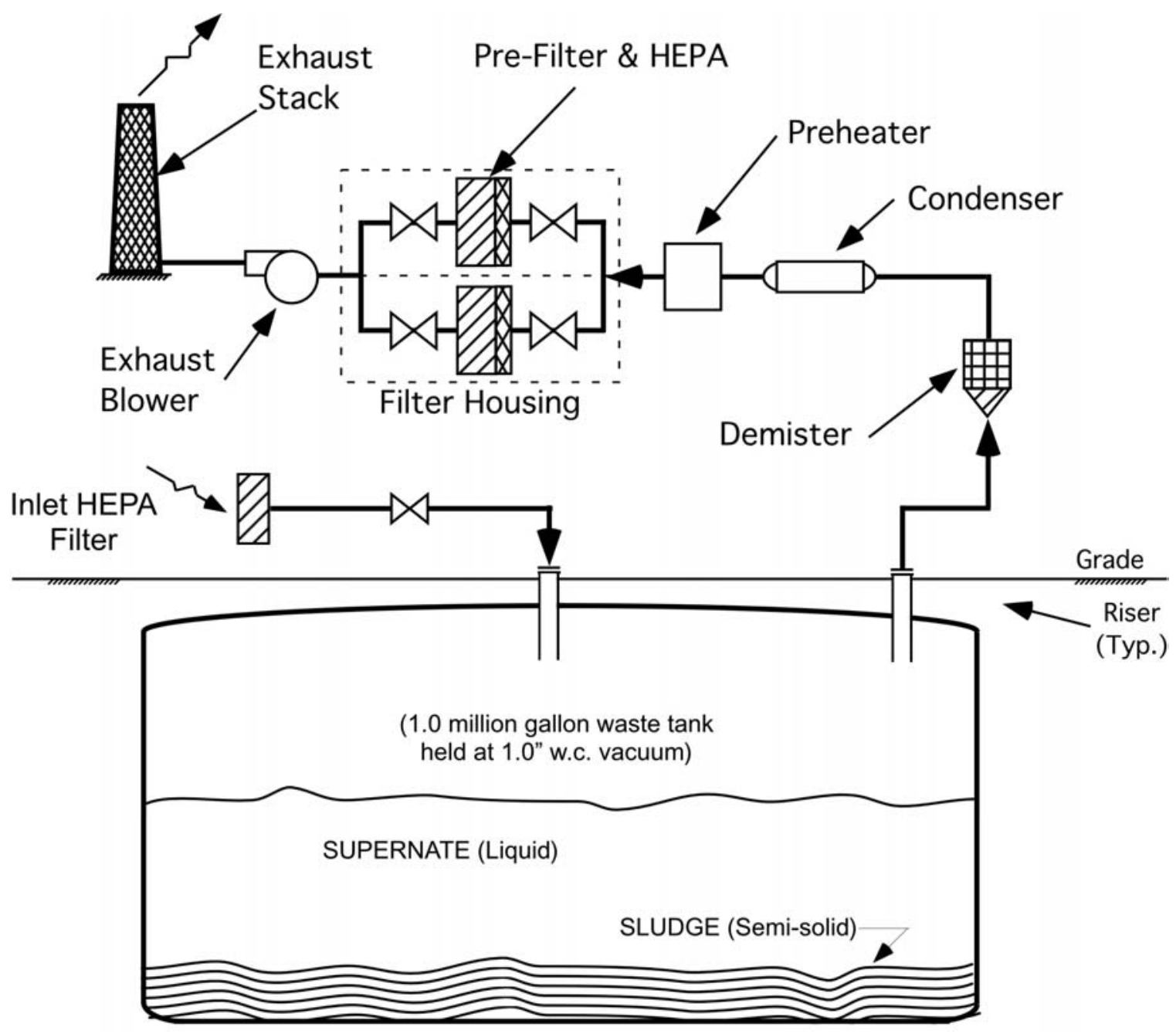

\section{Figure 1: Typical HLW Tank Ventilation System Flow Diagram}

Under funding from the DOE Tanks Focus Area (TFA), the National Energy Technology Laboratory (NETL) issued a "Request for Proposals" late in 1999 to identify vendors conducting research in the area of in situ cleanable/regenerative filters or vendors interested in pursuing such technology. A technical evaluation was conducted on the proposals. Based on the proposals reviewed, CeraMem Corporation (Waltham, Massachusetts) and Mott Corporation (Farmington, Connecticut) were selected to support this research program. In the initial phase of the program, CeraMem and Mott developed small test units (lab scale filters) that demonstrated HEPA filter particle retention performance and ability to be regenerated by cleaning in situ using an aqueous solution. CeraMem provided a ceramic monolith filter and Mott provided a sintered metal filter. Proof of principle for an in situ cleanable HEPA filter was a success with the lab scale filters, which led to the full-scale single element work with the ceramic and sintered metal filters. ${ }^{(2)}$

Through the Tanks Focus area, this technology was shared with other locations such Idaho National Engineering Laboratory (INEL), West Valley and Lawrence Livermore National Laboratory (LLNL). At INEEL, simulated Calcine transfer testing was conducted using small-scale ceramic filters with success. ${ }^{(3)}$ SRTC provided technical support to INEL throughout the small scale testing. Full-scale ceramic filters were provided to LLNL for bio-terrorism research. LLNL was in need of a robust filter media where bacteria such as anthrax could be destroyed in the HEPA filter using high temperatures or antiseptic solutions. 
A design review was conduct on the full-scale design of Mott Corporation and CeraMem Corporation. The design review took place during December 2001 at the Savannah River Research Campus in Aiken, South Carolina. Information on the design review is located in the Job Folder \# 22692. ${ }^{(4)}$ Below is a list of participants for the design review.

Name

Affiliation

Adamson, Duane

WSRC/SRTC

Adkins, Brannen

WSRC/HLW

d'Entremont, Paul

WSRC/HLW

Malhotra, Jeet

DOE/NETL

Priebe, Steve

INEEL/TMFA

Restivo, Mike

WSRC/SRTC

Terry, Mike

Wagoner, Charles

LANL/TFA

DIAL

Mott Corporation

Amara, Alexandra

Fahey, Tom

Mott Corporation

Ramos, Gil

Mott Corporation

Rubow, Ken

Mott Corporation

Mott Corporation

CeraMem Corporation

Goldsmith, Bob

CeraMem Corporation

Paquette, Phil

CeraMem Subcontractor

Also during the full-scale system design review, the International Union of Operating Engineers National Hazmat Program conducted a human factors assessment on both the Mott and CeraMem full-scale systems. ${ }^{(5)}$ Member of the assessment team:

Booth, Chip

Jenison, Mary

IVOE/OENHP

Kovach, John

DOE/HQ

Harrison, Jeana

IVOE/OENHP

IVOE/OENHP

Another important review of this program was conducted by the American Society of Mechanical Engineers (ASME). The ASME completed a Peer Review of the Alternative Filtration Program during September 2000 in Richland, Washington. ${ }^{(6)}$

\section{INTRODUCTION}

The vendors, Mott Corporation and CeraMem Corporation were asked to manufacture full-scale single elements for research and testing. Figure 2 is a picture of the full-scale ceramic filter element manufactured CeraMem and their subcontracts. 


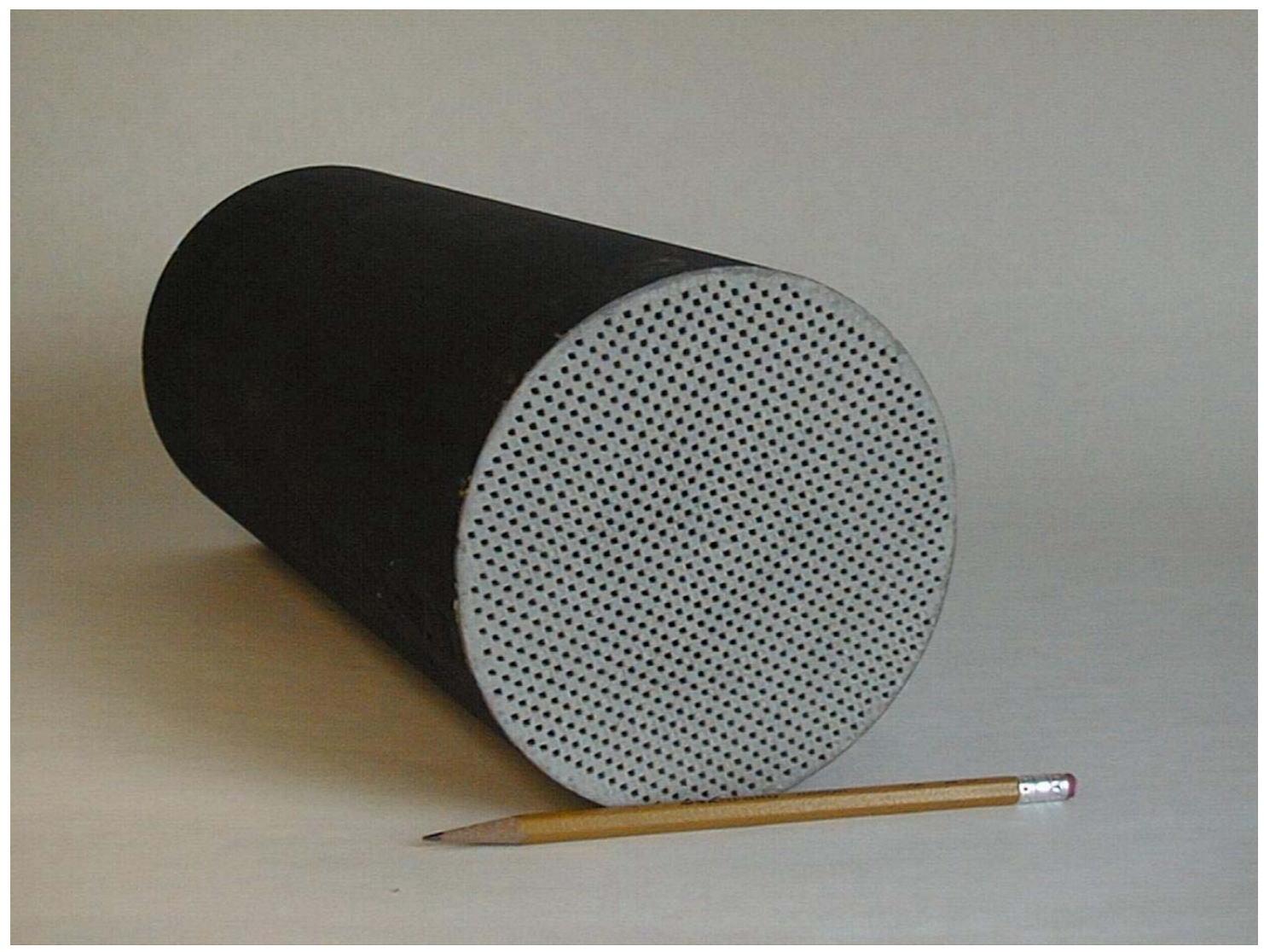

\section{Figure 2: Full-scale Ceramic Filter Element}

Below are the characteristics of the full-scale ceramic filters tested in this phase of the program:

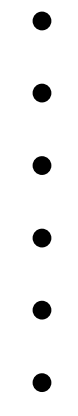
Monolith Membrane Support: Membrane Coating:

Overall Element Dimensions:

Monolith Cell Size:

Monolith Cell Wall Thickness:

Filtration Surface Area:
Silicon carbide

Glass-frit-bonded zirconium silicate

5.66" diameter x 12" long

0.079,

$0.0315 ”$

$18.5 \mathrm{ft}^{2}$

The ceramic filter media is a "dead-end" monolith filter. The passageway ends are plugged with ceramic cement in an "alternate, checkerboard pattern" as depicted in Figure 3. The dirty air with particulate matter enters the filter media and the gas flow is constrained to pass through the monolith walls separating inlet and outlet passageways. The membrane coating covers the passageway walls, and the entrained particles are filtered from the air onto the surface of the microporous membrane. The clean air flows down the outlet passageways and is exhausted from the filter. When installed in the filter housing, a boot seal is required at both ends of the filter to prevent leakage between the filter and the filter housing. 


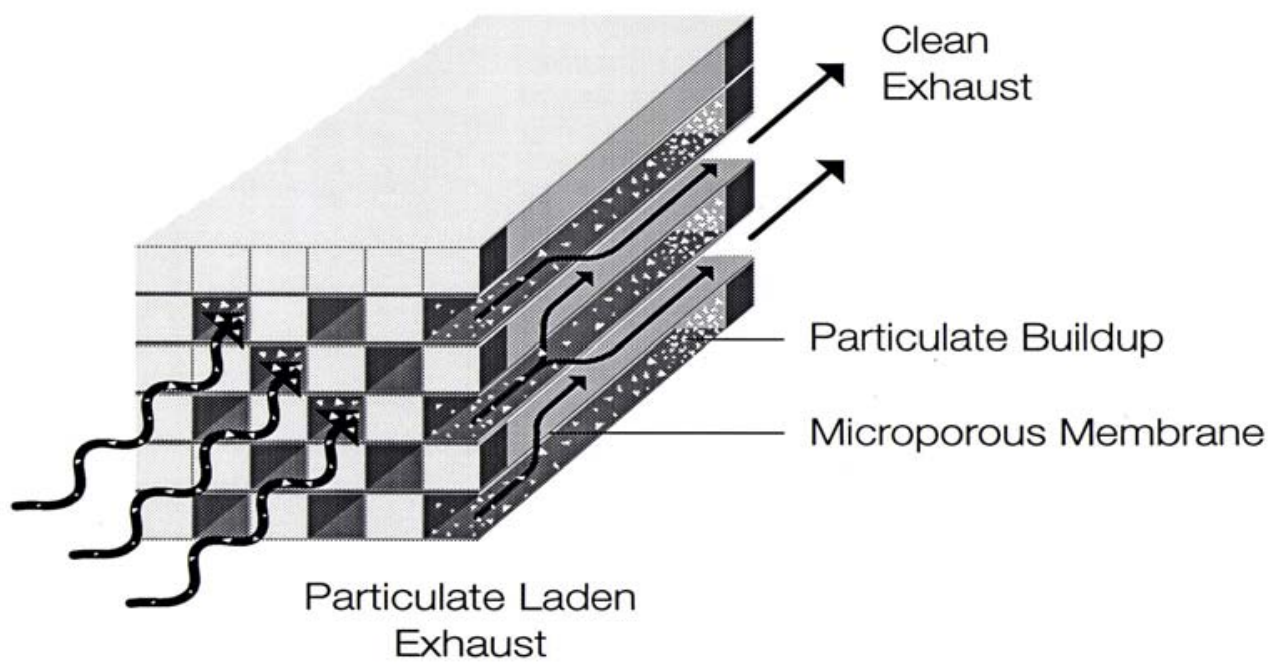

Figure 3: Airflow Path Ceramic Filter Media

Figure 4 shows a photomicrograph of a cross-section view of the silicon carbide (SiC) monolith pore structure with a membrane surface coating, with a pore size between $0.2-0.5 \mu \mathrm{m}$. This ceramic membrane provides a relative low-pressure drop (for a robust media) while obtaining HEPA filter retention efficiency. A literature search found that there is historical precedent for the use of $\mathrm{SiC}$ in nuclear applications. The material performs well in a high radiation environment. ${ }^{(7)}$

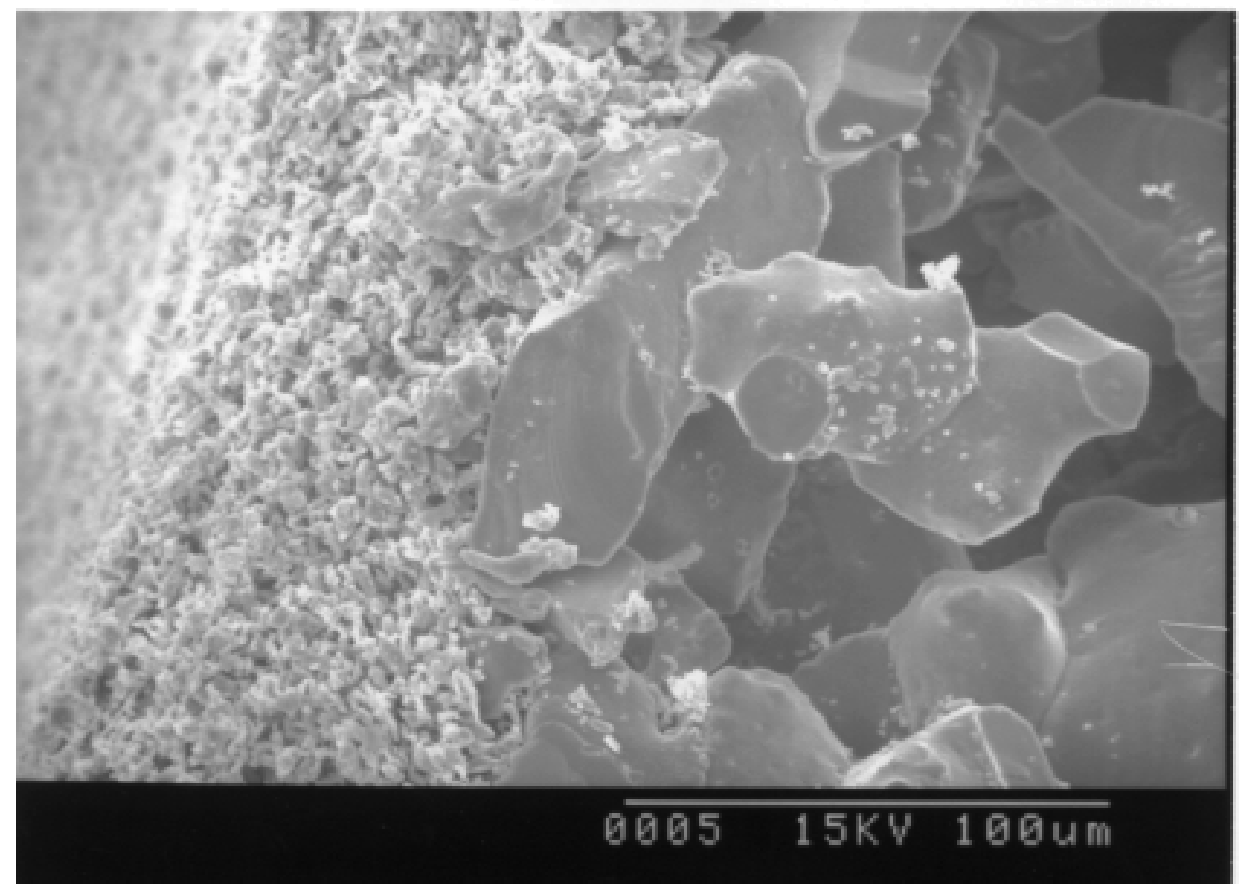

Figure 4: Cross-Sectional Micrograph of Membrane/Monolith Wall Structure 
Figure 5 is a photograph of three sintered metal filter elements manufactured by Mott Corporation. Note that stainless steel ring have been welded on each end of the sintered Ni metal media. The vendor was successful in welding the porous $\mathrm{Ni}$ media to the solid body stainless steel with out reducing the particle retention capabilities of the media.

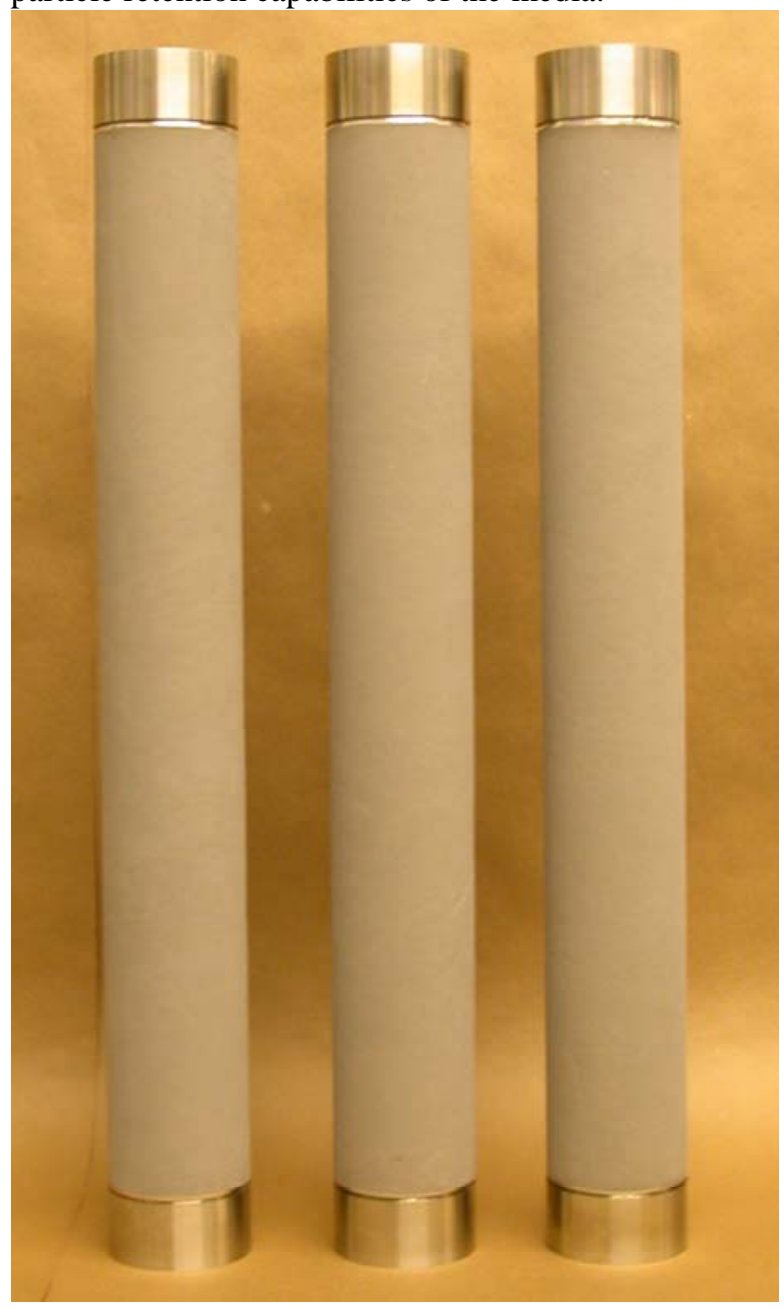

\section{Figure 5: Full-scale Sintered Metal Filter Element}

Below are the characteristics of the full-scale sintered metal filters tested in this phase of the program.

- Filter Media Material:

- Ni Particle Size:

- Filter Diameter:

- Media Length:

- Media Wall Thickness:

- Filtration Surface Area:
Nickel 200

2- $4 \mu \mathrm{m}$

$3.0 "$

22.3”

$0.085 "$

$1.36 \mathrm{ft}^{2}$

The inner-diameter (ID) of the tube filter is the filter inlet, where the particulate matter is filtered from the air stream. The clean air then flows through the filter wall to exit the filter. For the full-scale system, approximately twenty-four elements would be welded into the housing. The sintered metal filter is cleaned 
in situ via spraying the dirty side (ID of the tube) of the filter. Each element will have a single spay nozzle for cleaning the filter in situ. The full-scale filter housing assembly would be an all welded construction with no seals or gaskets. The Ni media provides high particle retention efficiencies but has a small surface area in a given geometry. The small surface area in a given geometry results in a higher-pressure drop than the ceramic filter for a given flow.

Figure 6 shows photomicrograph, magnified 1000 times, of the sintered Nickel media with pore sizes between $0.2-0.5 \mu \mathrm{m}$.

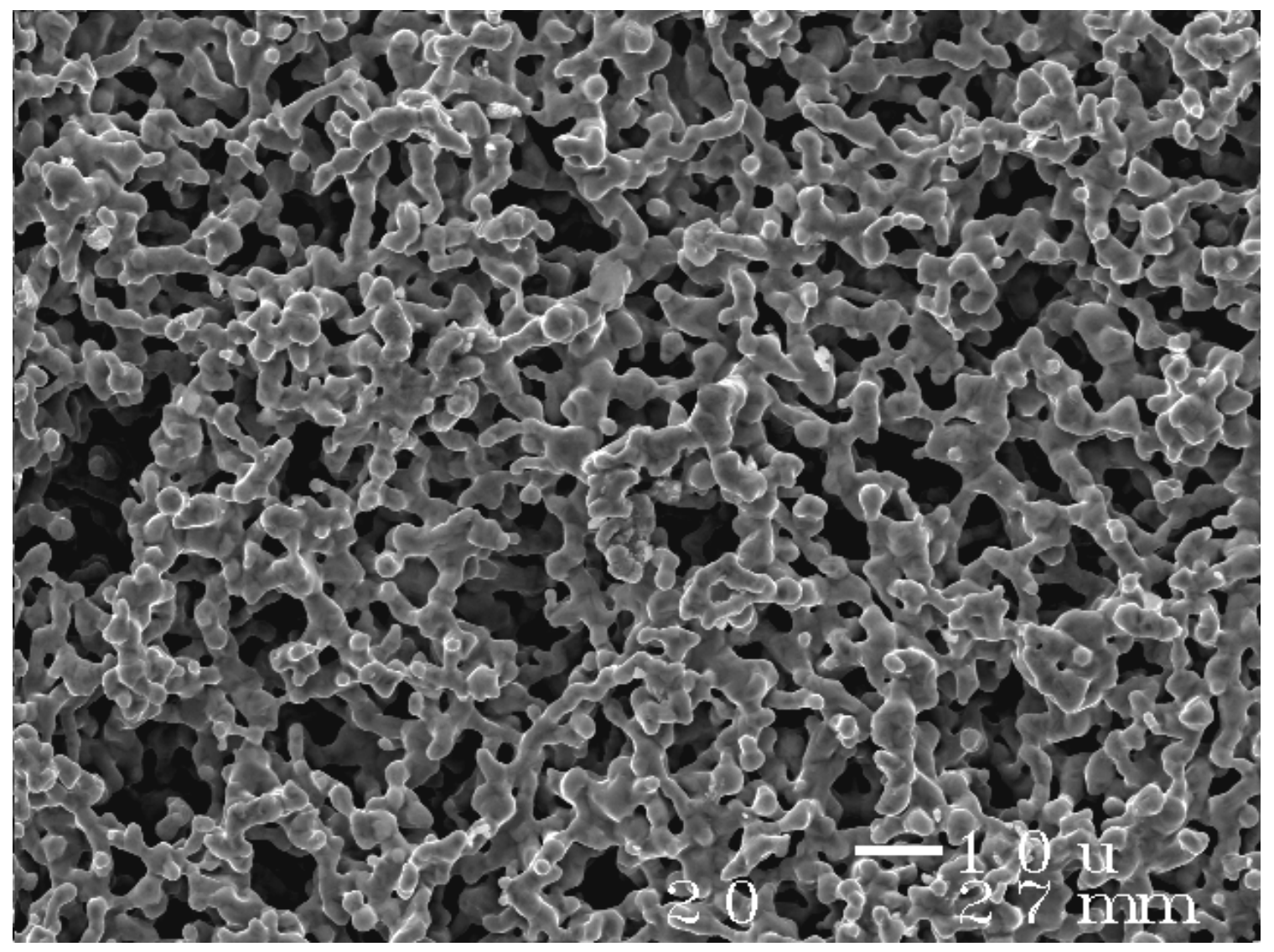

\section{Figure 6: Micrograph of Sintered Ni Media}

\section{TEST LOOP DESCRIPTION}

The full-scale single element HEPA filter test apparatus (HFTA) was constructed in the Engineering Development Laboratory (EDL) at the Savannah River Technology Center. A photo of the apparatus is shown in Figure 7. The HFTA was designed to simulate the conditions that challenge conventional filters on the HLW tanks at SRS. 


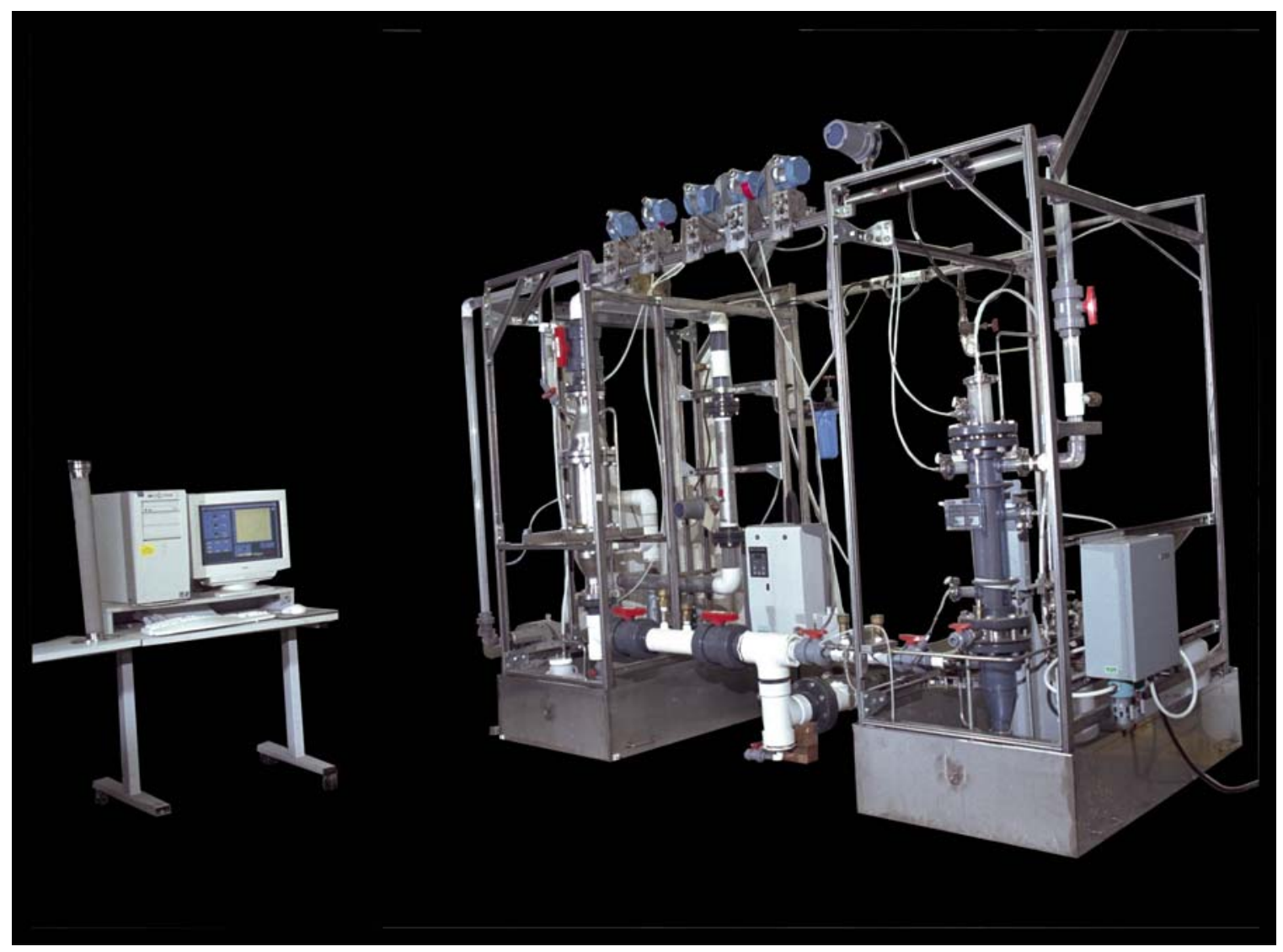

\section{Figure 7: Full-scale Single Element HEPA Filter Test Apparatus}

Testing was conducted per approved procedure. ${ }^{(8)}$ Approximately $130 \mathrm{cfm}$ of air entered the system and was filtered using a conventional HEPA filter. The filtered air was split, with $100 \mathrm{cfm}$ flowing through the ceramic filter and $30 \mathrm{cfm}$ flowing through the metal filter. A separate vacuum pump was used to pull the air across each filter as depicted in the schematic of the HFTA, Figure 8.

The HFTA was designed such that one filter could be cleaned while the other remained online for testing. The system operated continuously ( 24 hours a day, 7 days a week) until the differential pressure across the filter(s) increased by $20 \%$ or more due to particulate matter build up on the surface of the filter media. Once a filter became soiled from the simulated operation, it was cleaned in situ. The sintered metal filter was cleaned via spraying the inlet side (inner diameter) of the filter with an aqueous solution, oxalic acid and de-ionized water. The ceramic filter was cleaned via back flushing an aqueous solution, $10 \%$ nitric acid and de-ionized water. After the in situ wash cycle, the filters were returned to operation for continuous testing.

The data from the experiment were recorded by the data acquisition system (DAS) using calibrated instrumentation. A list of the calibrated instruments and their corresponding M\&TE numbers is shown in the instrumentation section of this report. Data that were recorded by the DAS include $\mathrm{dP}$ and flow across the filters, and temperature in the filter housings. Other data pertaining to the testing was recorded manually in the Laboratory Notebook. ${ }^{(9)}$ 


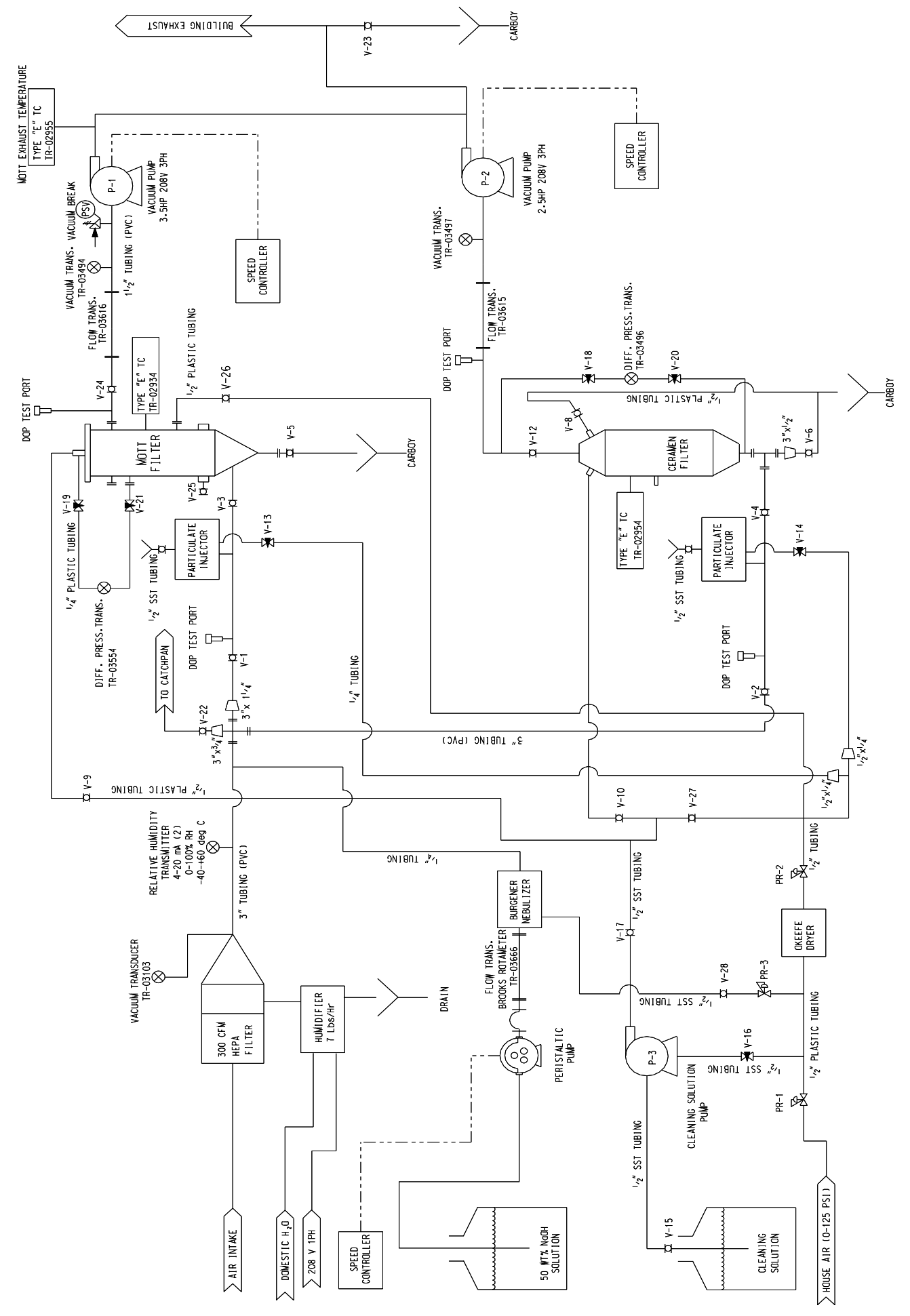

Figure 8: HFTA Schematic 


\section{Test Solutions}

During small scale testing, the spent cleaning solutions (after washing the filters in situ) were analyzed for analytes that were collecting on the filter media. ${ }^{(10)}$ From the analysis one could determine what analytes were collecting on the filter media from the simulant. These materials (and atmospheric dust), neglecting the radioactive constituents, are believed to be responsible for plugging the existing HEPA filters in the HLW tanks. The test solutions did not contain radioactive materials and only one solution challenged the filters at a time. The formulations for the challenge materials are shown below.

$\begin{array}{ll}\text { HLW Sludge Particle } \\ \mathrm{Fe} & 90 \% \\ \mathrm{Al} & 10 \%\end{array}$

Particles were injected from the dust reservoir into the air stream using a small purge of house air.

HLW Salt Particles

$\mathrm{NaOH}$ (Sodium Hydroxide)

Material was injected via wet suspension using a nebulizer.

South Carolina Road Dust

South Carolina road dust was used to simulate atmospheric dust around SRS. The dust consisted of topsoil taken from a garden in Aiken County. The soil was dried in an oven to remove the moisture and particles larger than 75 microns were sifted out, giving a large distribution of particle sizes to challenge the filters. The dust was slowly injected from the dust reservoir into the air stream using a small purge of house air.

\section{INSTRUMENTATION/EQUIPMENT}

\begin{tabular}{|c|c|c|c|}
\hline Instrumentation & M\&TE & Range & Accuracy (full scale) \\
\hline Vacuum Transducer & TR-03103 & 0-20" w.c. & \pm 0.2 " w.c. \\
\hline Air Flow Transmitter & TR-03615 & $0-250 \mathrm{scfm}$ & $\pm 4 \%$ F.S. \\
\hline Air Flow Transmitter & TR-03616 & $0-150 \mathrm{scfm}$ & $\pm 4 \%$ F.S. \\
\hline Diff. Pressure Transmitter & TR-03554 & 0 - 750" w.c. & \pm 0.08 psid \\
\hline Diff. Pressure Transmitter & TR-03496 & 0 - 750" w.c. & \pm 0.08 psid \\
\hline Diff. Pressure Transmitter & TR-03494 & 0 - 750" w.c. & \pm 0.08 psid \\
\hline Diff. Pressure Transmitter & TR-03497 & 0 - 750" w.c. & \pm 0.08 psid \\
\hline Relative Humidity Transmitter & TR-03557 & $5-95 \%$ RH & $\pm 1^{\circ} \mathrm{F}$ \\
\hline Rotameter & TR-03666 & $0-80 \mathrm{ml} / \mathrm{min}$ & $\pm 1 \mathrm{ml} / \mathrm{min}$ \\
\hline Temperature Transmitter (TC) & TR-02955 & $-200-900{ }^{\circ} \mathrm{C}$ & $\pm 1.7^{\circ} \mathrm{C}$ \\
\hline Temperature Transmitter (TC) & TR-02954 & $-200-900{ }^{\circ} \mathrm{C}$ & $\pm 1.7^{\circ} \mathrm{C}$ \\
\hline Temperature Transmitter (TC) & TR-02934 & $-200-900{ }^{\circ} \mathrm{C}$ & $\pm 1.7^{\circ} \mathrm{C}$ \\
\hline Temperature Transmitter (TC) & TR-02955 & $-200-900{ }^{\circ} \mathrm{C}$ & $\pm 1.7^{\circ} \mathrm{C}$ \\
\hline
\end{tabular}

\section{Equipment}

Vacuum pump/blower, Siemens Model 2BH7520OAK22, was used for the metal filter, with variable frequency controller. Vacuum breaker supplied with blower, set to 15 in $\mathrm{Hg}$. Inlet side. Vacuum pump/blower, Regenair Model R5325A-2, was used for the ceramic filter, with variable frequency controller Humidity System, DGH Systems Model SD 103PO 
Pressure Regulator, 0-15 psig, PR-1

Pressure Regulator, 0-60 psig, PR-2

Nebulizer, Burgener Model Special 30A

Dryer, O'Keefe

Diaphragm Pump, for filter cleaning, Wildon model M1/ST/TF/TF/ST

Spray Nozzle, for filter cleaning, Bete Fog Nozzle Model \# WL 1 1/2 90

The HFTA inlet air was filtered using a 300 cfm Flanders HEPA Filter, Order \# AB74679A.

Data for this experiment were obtained using the Data Acquisition System (DAS) listed below.

PC Computer

PC System Version

Labview®

Labview ${ }^{\circledR}$ Chassis

Labview ${ }^{\circledR}$ Module

Labview ${ }^{\circledR}$ Terminal Panel
00389397 Dell OptiPlex Gxip

Win 95

Version \# 5.1 National Instruments

SCXI-1000

SCXI-1102

SCXI-1303

\section{RESULTS AND DISCUSSION}

- $\quad$ The sintered metal and ceramic full-scale single filter elements can be manufactured with HEPA grade particle retention, $99.97 \%$ efficiency or greater.

- $\quad 68 \%$ of the sintered metal filter tested had $99.999 \%$ particle retention.

- $\quad$ Manufacturing data suggest that the ceramic filter could be manufactured as a pre- HEPA filter with various particle retention efficiencies.

- $\quad$ The organic material, DOP, used for particle retention was found not to be the ideal challenge material for the ceramic and sintered metal filter media.

- $\quad$ The sintered metal and ceramic full-scale single elements operated in a high humidity environment with little or no effect on its operation.

- $\quad$ The sintered metal and ceramic filters both regenerated well in situ after plugging with HLW simulant particles.

- $\quad$ The filters regenerated well from salt and sludge particles using only de-ionized water. However, there is a point where a more aggressive cleaning solution is required to reduce the surface tension.

- $\quad$ The sintered metal and ceramic filters did not regenerated well after plugging with road dust

- $\quad$ The Mott single nozzle spray system design may require improvements before going to full-scale cold testing to achieve greater surface area coverage

- $\quad$ Filters retained $99.97 \%$ or greater retention after the many plugging/ in situ cleaning cycles, indicating that the filter media is not deteriorating from repeated cleanings.

\section{Particle Retention Testing At ORNL}

Particle retention testing was conducted on the full-scale filter elements at the Oak Ridge Filter Test Facility (FTF) to determine their filtering efficiency. Air Techniques International (ATI) who operates the Department of Energy facility modified their FTF test equipment to conduct the efficiency tests. The vendors were asked to optimize the particle retention verses the $\mathrm{dP}$ across the filter media during manufacturing. Each vendor was to supply approximately 30 filter elements. After testing, the filters were returned to the vendors except for a selected few that would undergo simulant testing and display at SRTC.

ATI challenged the filters with di-octyl phthalate (DOP) which has been the standard for many years when determining the particle retention efficiency of conventional HEPA filters. The DOP is an organic and the particles are $0.3-\mu \mathrm{m}$ diameter near mono-disperse. The filters had to display a particle retention efficiency of $99.97 \%$ or greater to pass the test. 
A total of 28 ceramic and 38 sintered metal full-scale filter elements were supplied to the FTF. Table 1 in appendix A gives the results for the ceramic filter. A total of 9 ceramic filters passed the particle retention test with greater than $99.97 \%$ efficiency. The high number of filters that failed is not seen as a negative, but indicates that the vendor could vary manufacturing techniques to optimize the $\mathrm{dP}$ vs. retention that was requested. Each ceramic filter was tested at two different flows. Testing results proved that fullscale ceramic filter elements with HEPA retention could be manufactured. Also varying manufacturing techniques provided critical manufacturing data to the vendor. Data indicates that the vendor may be able to manufacture prefilters with various retention efficiencies at a given particle size requirements.

Table 2 in appendix A gives the results of the sintered metal full-scale filters. 34 of the 35 sintered metal filters tested passed the particle retention test with greater than $99.97 \%$ efficiency. The sintered metal filters have a very high retention. Due to the manufacturing procedures for sintered metal filters, the vendor found it very difficult to optimize dP vs. particle retention. $68 \%$ of the filters tested had $99.999 \%$ particle retention efficiency, which is over a magnitude higher in filtration than is required for a HEPA filter. A high percentage of the filters were tested after the stainless steel ends were welded to the media, indicating the sintered metal media particle retention is not being impacted from welding. However, the weld region of the media is a concern, since two filters broke in this area during normal handling.

Both DOP and Poly Alpha Olefin (PAO) were found to increase the pressure drop across the alternative media. Also, these materials are difficult to remove from the filter media via existing cleaning methods. These organic materials may not be the ideal challenge materials for conducting particle removal efficiency on the alternative media. Other methods may need to be investigated for conducting particle retention tests on the alternative media. Much work has been done in Europe on testing the efficiency of conventional HEPA filters using $\mathrm{NaCl}$ particles with a high degree of success. It would be advantageous for this program to investigate particle removal efficiency using $\mathrm{NaCl}$ as a potential standard for the alternative media. Groundwork was laid with the Energy \& Environmental Research Center (EERC) at the University of North Dakota and the Diagnostic Instrumentation and Analysis Laboratory (DIAL) at Mississippi State University on testing the retention efficiencies of the alternative media using other material such as $\mathrm{NaCl}$ as the challenge material. No testing in this area was conducted due to the lack of funding.

\section{Simulant Testing at SRTC}

Cleaning curves in Appendix B depicts the loading and cleaning cycles for both the sintered metal and ceramic filters for the sludge, salt and road dust tests. The curves were created from data that was logged every 10 minutes using a data acquisition system. Ceramic filter, H-20 with a particle retention efficiency of $99.972 \%$, and sintered metal filter, \#117 with a $99.999 \%$ efficiency, were chosen as the test filters for the simulant testing at SRTC. Initially Mott filter \# 5 was installed as the test filter, but was removed from testing at Mott Corporation's request due to manufacturing concerns with the filter media and the ability to clean the filter in situ.

The ceramic filter was loaded with sludge particles and cleaned in situ four different cycles. The sludge test lasted approximately 1,800 hours as shown in Curve 1 of Appendix B. In this loading test, the filter was cleaned only with de-ionized (DI) water where the filter regenerated well. However, there was a small pressure drop, approximately 2" wc, that was not recovered. DI water was also found to clean the ceramic filter well during the 2,000 hour salt test as shown in Curve 3. The filter was loaded with salt and cleaned in situ four cycles with the filter media loaded to over $100 \%$ of the clean filter dP. This effective regeneration indicates that the filter could recover from a worst case scenario in actual field condition without damage to the filter.

The sintered metal filter was found harder to regenerate in situ when compared to small scale testing. This may be due to the design change to a single nozzle used to spray the dirty side (ID) of the filter. Also the cleaning solutions, oxalic acid recommended by the vendor may not be the best cleaning solution for the Ni sintered metal. Curve 2 in Appendix B depicts the 1000-hour hostile sludge test where the filters cleaned well but did not recover to a clean filter status. 
The sintered metal filter regenerated well in situ during the 2,000 hour salt test where the filter was loaded and cleaned in situ four different cycles. Depicted in Curve 4 the filter was loaded to over 200" wc $\mathrm{dP}$ across the filter and regenerated to approximately 100 " wc $\mathrm{dP}$, indicating that the filter will not break through or damage the media due to heavy loading.

The ceramic and sintered metal filters performed well in the hostile environment during the sludge and salt test. However for the overall test campaign (approximately 5,000 hours), the $\mathrm{dP}$ across the media for both filters did not return to a clean filter status. It was during the SC road dust test (final challenge test) that most of the dP increase occurred that did not recover from the in situ cleanings. During the hostile SC road dust test, a $38 \%$ increase in $\mathrm{dP}$ across the ceramic media occurred (see Curve 5) and 32\% $\mathrm{dP}$ increase of the sintered metal (see curve 6). Additional cleaning cycles were completed on both filters, with no recovery in the increased $\mathrm{dP}$.

This data does not necessarily mean the filters will not completely regenerate in situ when operated in a realistic manner. During this testing, extremely hostile conditions were created, such as loading the filters to over $100 \%$ clean filter dP (i.e. 13" wc clean loaded to $29 "$ wc for the ceramic filter). This data indicates that in actual field conditions, the filters should be cleaned in situ when the $\mathrm{dP}$ increase is much less than $20 \%$.

The in situ cleaning required approximately five liters of cleaning solution to clean each filter. Using this system on a HLW tank, the spent cleaning solution would be drained to the tank with no new waste streams being created.

The full-scale ceramic (H-20) and sintered metal (\#117) test filters that were subjected to approximately fourteen loading/cleaning cycles, were returned to the Oak Ridge FTF for a post particle retention test. The results were positive that there was little or no change in the retention capability of both the ceramic and sintered metal filters. Both filters had greater than HEPA retention, 99.97\% efficiency. This indicates that the filter media is not deteriorating when undergoing repeated plugging and cleaning cycles.

Potentially there are many applications across the DOE complex and commercially that this technology could add value. In the area of bio-terrorism research, materials such as anthrax can remain in a dormant state for many years. Facilities conducting research with such materials would have the option to destroy the organisms in the HEPA filters using high temperatures or antiseptic solutions before the filters are manually handled and/or sent to solid waste. During wild fires, heavy smoke and smoke borne particulate may plug the alternative filter, but test results indicate that the plugged condition will not cause filter failure and/or breakthrough.

\section{CONCLUSIONS}

Test results indicate that filter media other then glass fiber hold great promise for use as HEPA filters for nuclear grade applications. In addition, testing has shown that the ceramic and sintered metal media are robust and can be regenerated in situ with a potential for a long life. These robust filters reduce the potential of HEPA filter break through failure due to high moisture content or fire.

The ceramic and sintered metal filters were plugged many times with HLW simulants and recovered well after being cleaned in situ with aqueous solution. The full-scale test filters passed both the pre- and post-particle retention test with an efficiency of $99.97 \%$ or better. The Data indicates that the media is not deteriorating or breaking down due to the in situ cleaning cycles. 


\section{REFERENCES:}

1. Defense Nuclear Facilities Safety Board Technical Report, DNFSB/TECH-23, May 1999.

2. Adamson, D.J. "Experimental Investigation Of Alternative In Situ Cleanable HEPA Filters" WSRC-TR-99-000486, January, 2000

3. Griffith, D., Chien, D. N. "Cleanable Filter Selection and Test Results for Simulated Calcine Transfer" INEEL/EXT-01-01257, September, 2001

4. Job Folder \# 22692, In-Situ Cleanable Filters, EES Document Control, 730-A

5. International Union of Operating Engineers National HAZMAT Program, Alternative HEPA Filtration CeraMem Ceramic HEPA Filter, OENHP \#2001-11 Version A; Alternative HEPA Filtration Mott HEPA Filter, OENHP \#2001-18 Version A; DOE Technology Management System \# 2091

6. American Society of Mechanical Engineers Peer Review, "Alternative Ceramic High Efficiency Particulate Air Filtration System" ASME/CRTD-RP-0016, September, 2000 and "Alternative Metallic High Efficiency Particulate Air Filtration System” ASME/CRTD-RP-0015, September, 2000

7. Norato, M.A., "Literature Review of Radiation Resistance of Alternative HEPA Filter Media" SRTETF-2000-00022, September, 2000

8. Alternative In Situ Cleanable HEPA Filter Testing, Procedure FP-746 Revision 3, March 2002

9. Laboratory Notebook, "Single Element HEPA Filter Test, WSRC-NB-2000-00075

10. Adamson, D.J. "Experimental Investigation Of Alternative In Situ Cleanable HEPA Filters" WSRC-TR-98-00382, October, 1998 


\section{Appendix A}

\section{Particle Retention Test Results}

Table 1:

Table 2:
Ceramic Full-scale Filters

Sintered Metal Full-scale Filters 
Table 1. Particle Retention Results Ceramic Full-scale Filters

\begin{tabular}{|c|c|c|c|c|}
\hline $\begin{array}{c}\text { FILTER SERIAL } \\
\text { NUMBER }\end{array}$ & FLOW THROUGH MEDIA & $\begin{array}{l}\text { Resistance } \\
\text { Inches w.c. }\end{array}$ & $\begin{array}{c}\text { Penetration } \\
\%\end{array}$ & $\begin{array}{c}\text { Efficiency } \\
\%\end{array}$ \\
\hline \multirow{2}{*}{$\mathrm{H}-30$} & $125 \mathrm{cfm}$ & 21.2 & 6.8 & 93.2 \\
\hline & $25 \mathrm{cfm}$ & 8.5 & .33 & 99.67 \\
\hline \multirow{2}{*}{ H-29 } & $125 \mathrm{cfm}$ & 26.0 & 4.1 & 95.9 \\
\hline & $25 \mathrm{cfm}$ & 1.9 & 1.5 & 98.5 \\
\hline \multirow{2}{*}{ H-46 } & $125 \mathrm{cfm}$ & 26.8 & 2.1 & 97.9 \\
\hline & $25 \mathrm{cfm}$ & 2.8 & .95 & 99.05 \\
\hline \multirow[t]{2}{*}{ H-44 } & $125 \mathrm{cfm}$ & 23.2 & .014 & 99.986 \\
\hline & $25 \mathrm{cfm}$ & 1.4 & .001 & 99.999 \\
\hline \multirow[t]{2}{*}{ H-42 } & $125 \mathrm{cfm}$ & 25.6 & .016 & 99.984 \\
\hline & $25 \mathrm{cfm}$ & 1.4 & .001 & 99.999 \\
\hline \multirow[t]{2}{*}{ H-28 } & $125 \mathrm{cfm}$ & 26.1 & .018 & 99.982 \\
\hline & $25 \mathrm{cfm}$ & 1.8 & .001 & 99.999 \\
\hline \multirow[t]{2}{*}{ H-33 } & $125 \mathrm{cfm}$ & 27.2 & 3.6 & 96.4 \\
\hline & $25 \mathrm{cfm}$ & 2.1 & .72 & 99.28 \\
\hline \multirow[t]{2}{*}{$\mathrm{H}-31$} & $125 \mathrm{cfm}$ & 22.5 & .014 & 99.986 \\
\hline & $25 \mathrm{cfm}$ & 1.8 & .001 & 99.999 \\
\hline \multirow[t]{2}{*}{$\mathrm{H}-40$} & $125 \mathrm{cfm}$ & 26.5 & 3.2 & 96.8 \\
\hline & $25 \mathrm{cfm}$ & 2.1 & .56 & 99.44 \\
\hline \multirow[t]{2}{*}{$\mathrm{H}-43$} & $125 \mathrm{cfm}$ & 25.1 & .011 & 99.989 \\
\hline & $25 \mathrm{cfm}$ & 1.6 & .001 & 99.999 \\
\hline \multirow[t]{2}{*}{ H-39 } & $125 \mathrm{cfm}$ & 26.8 & 5.8 & 94.2 \\
\hline & $25 \mathrm{cfm}$ & 2.2 & 2.4 & 97.6 \\
\hline \multirow[t]{2}{*}{ H-47 } & $125 \mathrm{cfm}$ & 22.6 & .008 & 99.992 \\
\hline & $25 \mathrm{cfm}$ & 1.8 & .001 & 99.999 \\
\hline \multirow[t]{2}{*}{$\mathrm{H}-41$} & $125 \mathrm{cfm}$ & 25.2 & .007 & 99.993 \\
\hline & $25 \mathrm{cfm}$ & 1.6 & .001 & 99.999 \\
\hline 14 & $125 \mathrm{cfm}$ & 15.0 & 0.15 & 99.85 \\
\hline
\end{tabular}




\begin{tabular}{|c|c|c|c|c|}
\hline & $25 \mathrm{cfm}$ & 1.2 & 0.14 & 99.84 \\
\hline \multirow[t]{2}{*}{2} & $125 \mathrm{cfm}$ & 11.6 & 4.8 & 95.2 \\
\hline & $25 \mathrm{cfm}$ & 2.4 & 4.8 & 95.2 \\
\hline \multirow[t]{2}{*}{13} & $125 \mathrm{cfm}$ & 18.0 & .044 & 99.956 \\
\hline & $25 \mathrm{cfm}$ & 3.6 & .039 & 99.961 \\
\hline \multirow{2}{*}{10} & $125 \mathrm{cfm}$ & 15.4 & 0.13 & 99.87 \\
\hline & $25 \mathrm{cfm}$ & 3.6 & 0.18 & 99.82 \\
\hline \multirow[t]{2}{*}{9} & $125 \mathrm{cfm}$ & 18.8 & .077 & 99.923 \\
\hline & $25 \mathrm{cfm}$ & 4.4 & 0.21 & 99.79 \\
\hline \multirow[t]{2}{*}{7} & $125 \mathrm{cfm}$ & 21.8 & .037 & 99.963 \\
\hline & $25 \mathrm{cfm}$ & 4.8 & .073 & 99.927 \\
\hline \multirow{2}{*}{ H-26 } & $125 \mathrm{cfm}$ & 14.2 & .10 & 99.9 \\
\hline & $25 \mathrm{cfm}$ & 1.0 & .11 & 99.89 \\
\hline \multirow[t]{2}{*}{$\mathrm{H}-25$} & $125 \mathrm{cfm}$ & 26.0 & .018 & 99.982 \\
\hline & $25 \mathrm{cfm}$ & 2.0 & .016 & 99.984 \\
\hline \multirow[t]{2}{*}{$\mathrm{H}-21$} & $125 \mathrm{cfm}$ & 28.0 & 45.0 & 55.0 \\
\hline & $25 \mathrm{cfm}$ & 7.0 & 4.8 & 95.2 \\
\hline \multirow[t]{2}{*}{ H-19 } & $125 \mathrm{cfm}$ & 17.0 & .035 & 99.965 \\
\hline & $25 \mathrm{cfm}$ & 1.8 & .035 & 99.965 \\
\hline \multirow[t]{2}{*}{$\mathrm{H}-22$} & $125 \mathrm{cfm}$ & 28.0 & 48.0 & 52.0 \\
\hline & $25 \mathrm{cfm}$ & 6.4 & 14.0 & 86.0 \\
\hline \multirow[t]{2}{*}{$\mathrm{H}-20 * *$} & $125 \mathrm{cfm}$ & 14.8 & .028 & 99.972 \\
\hline & $25 \mathrm{cfm}$ & 1.8 & .019 & 99.981 \\
\hline \multirow[t]{2}{*}{$\mathrm{H}-24$} & $125 \mathrm{cfm}$ & 18.5 & 21.5 & 78.5 \\
\hline & $25 \mathrm{cfm}$ & 4.8 & 4.2 & 95.8 \\
\hline $\mathrm{H}-32$ & Damaged in Shipping & - & - & - \\
\hline $\mathrm{H}-34$ & Damaged in Shipping & - & - & - \\
\hline
\end{tabular}

** Simulant test filter at SRTC 
Table 2. Particle Retention Results Ni Metal Full-scale Filters

\begin{tabular}{|c|c|c|c|c|}
\hline $\begin{array}{c}\text { FILTER SERIAL } \\
\text { NUMBER }\end{array}$ & FLOW THROUGH MEDIA & $\begin{array}{l}\text { Resistance } \\
\text { Inches w.c. }\end{array}$ & $\begin{array}{c}\text { Penetration } \\
\%\end{array}$ & $\begin{array}{c}\text { Efficiency } \\
\%\end{array}$ \\
\hline 90 & $30 \mathrm{cfm}$ & 72 & .016 & 99.984 \\
\hline 82 & $30 \mathrm{cfm}$ & 90 & .022 & 99.978 \\
\hline 115 & $35 \mathrm{cfm}$ & 90 & .003 & 99.997 \\
\hline $117 * *$ & $31 \mathrm{cfm}$ & 91 & .001 & 99.999 \\
\hline 116 & $32 \mathrm{cfm}$ & 88 & .001 & 99.999 \\
\hline 114 & $32 \mathrm{cfm}$ & 88 & .001 & 99.999 \\
\hline 113 & $32 \mathrm{cfm}$ & 92 & .002 & 99.998 \\
\hline 91-010D & $32 \mathrm{cfm}$ & 91 & .008 & 99.992 \\
\hline 91-010-C & $32 \mathrm{cfm}$ & 92 & .001 & 99.999 \\
\hline 91-010-B & $32 \mathrm{cfm}$ & 94 & .001 & 99.999 \\
\hline $91-010-A$ & $32 \mathrm{cfm}$ & 94 & .001 & 99.999 \\
\hline 120 & $32 \mathrm{cfm}$ & 88 & .001 & 99.999 \\
\hline 104 & $32 \mathrm{cfm}$ & 94 & .001 & 99.999 \\
\hline $91-010-\mathrm{F}$ & $32 \mathrm{cfm}$ & 90 & .001 & 99.999 \\
\hline $91-010-\mathrm{E}$ & $34 \mathrm{cfm}$ & 90 & .001 & 99.999 \\
\hline 85 & $34 \mathrm{cfm}$ & 91 & .001 & 99.999 \\
\hline 126 & $32 \mathrm{cfm}$ & 94 & .001 & 99.999 \\
\hline 124 & $35 \mathrm{cfm}$ & 90 & .001 & 99.999 \\
\hline 122 & $33 \mathrm{cfm}$ & 91 & .001 & 99.999 \\
\hline 118 & $36 \mathrm{cfm}$ & 89 & .004 & 99.996 \\
\hline 129 & $32 \mathrm{cfm}$ & 92 & .001 & 99.999 \\
\hline 119-LB & $36 \mathrm{cfm}$ & 90 & .001 & 99.999 \\
\hline 128-LB & $32 \mathrm{cfm}$ & 92 & .001 & 99.999 \\
\hline 78-LB & $30 \mathrm{cfm}$ & 92 & .001 & 99.999 \\
\hline
\end{tabular}




\begin{tabular}{|c|c|c|c|c|}
\hline 79-LB & $32 \mathrm{cfm}$ & 90 & .001 & 99.999 \\
\hline 89-LB & $28 \mathrm{cfm}$ & 92 & .006 & 99.994 \\
\hline 127-LB & $32 \mathrm{cfm}$ & 90 & .001 & 99.999 \\
\hline 105-LB & $25 \mathrm{cfm}$ & 98 & .001 & 99.999 \\
\hline 125 & $35 \mathrm{cfm}$ & 95 & .032 & 99.968 \\
\hline A-3 & $35 \mathrm{cfm}$ & 94 & .002 & 99.998 \\
\hline A-4 & $35 \mathrm{cfm}$ & 91 & .025 & 99.975 \\
\hline$A-5$ & $32 \mathrm{cfm}$ & 94 & .001 & 99.999 \\
\hline$\# 1$ & $33 \mathrm{cfm}$ & 94 & .001 & 99.999 \\
\hline$\# 2$ & $33 \mathrm{cfm}$ & 99 & .001 & 99.999 \\
\hline 5 & $33 \mathrm{cfm}$ & 67 & .002 & 99.998 \\
\hline 4 & filter damaged during shipping & - & - & - \\
\hline A-1 & filter damaged during shipping & - & - & - \\
\hline$A-2$ & filter damaged during shipping & - & - & - \\
\hline
\end{tabular}

** Simulant test filter at SRTC 


\title{
Appendix B
}

\section{List of cleaning curves}

\author{
Curve 1: $\quad$ Sludge Solution, dP across CeraMem Filter \\ Curve 2: $\quad$ Sludge Solution, dP across Mott Filter \\ Curve 3: $\quad$ Salt Solution, dP across CeraMem Filter \\ Curve 4: $\quad$ Salt Solution, dP across Mott Filter \\ Curve 5: $\quad$ SC Road Dust, dP across CeraMem Filter \\ Curve 6: $\quad$ SC Road Dust, dP across Mott Filter
}




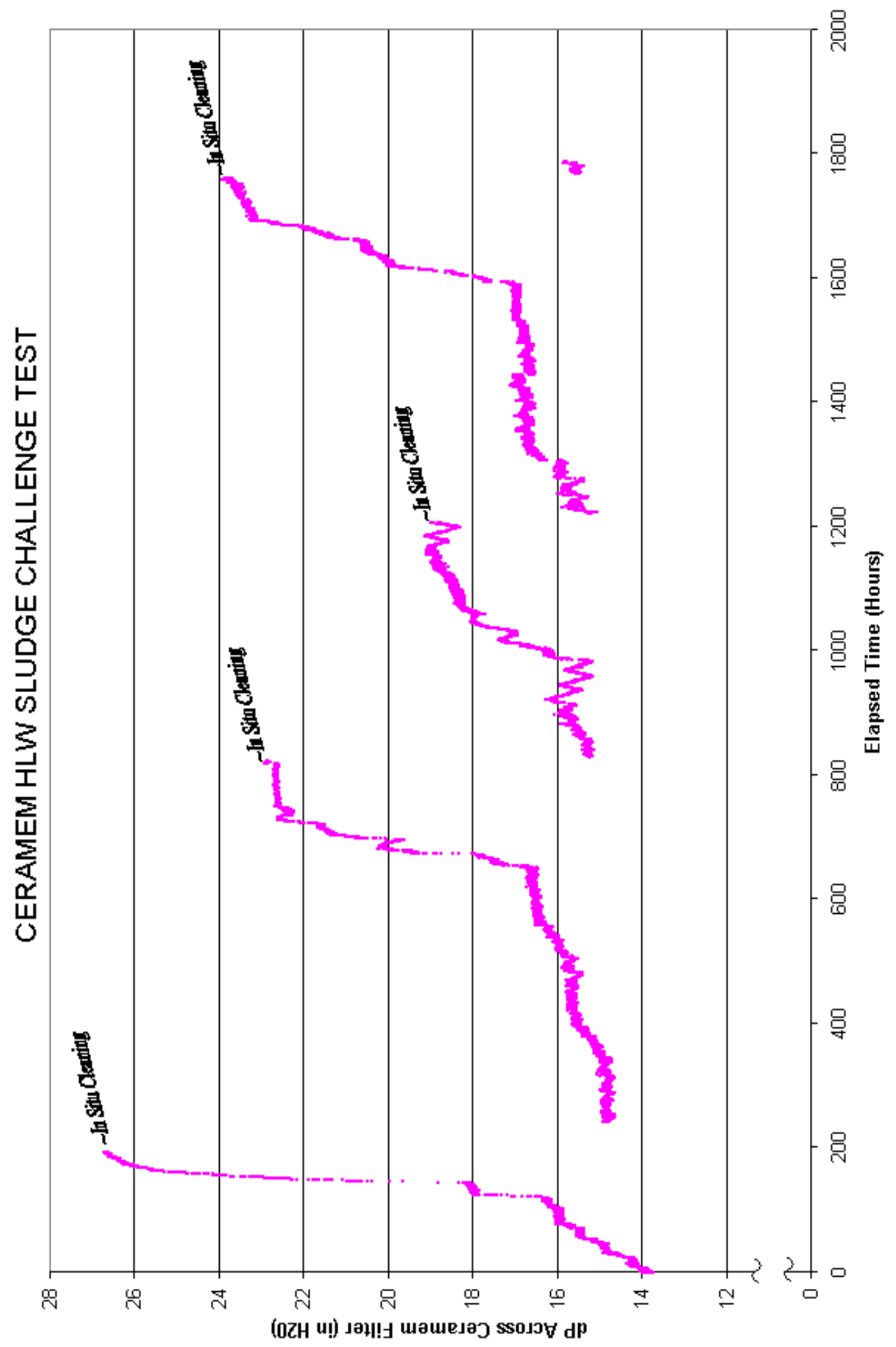

Curve 1 - Sludge Solution, dP across CeraMem Filter 


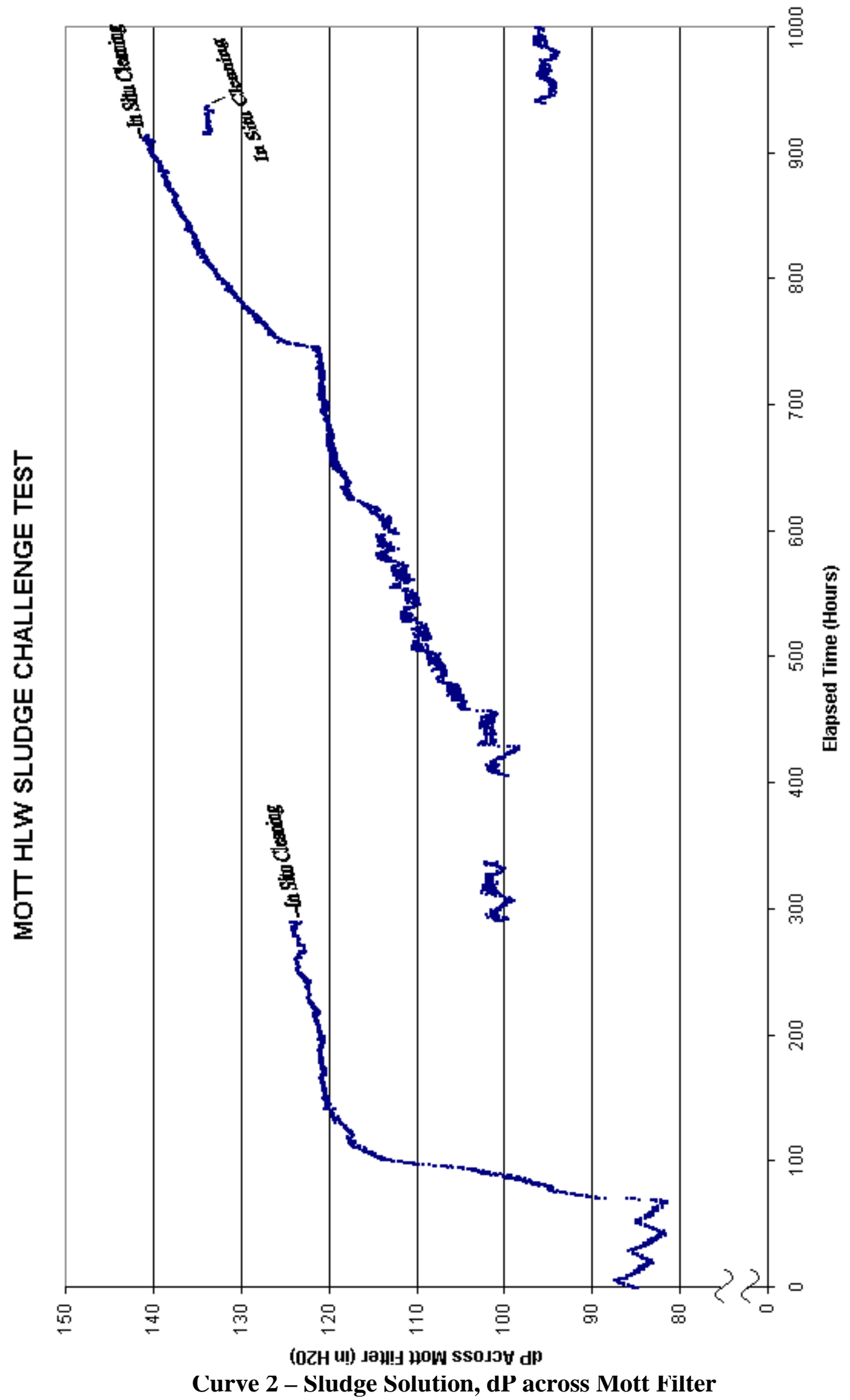




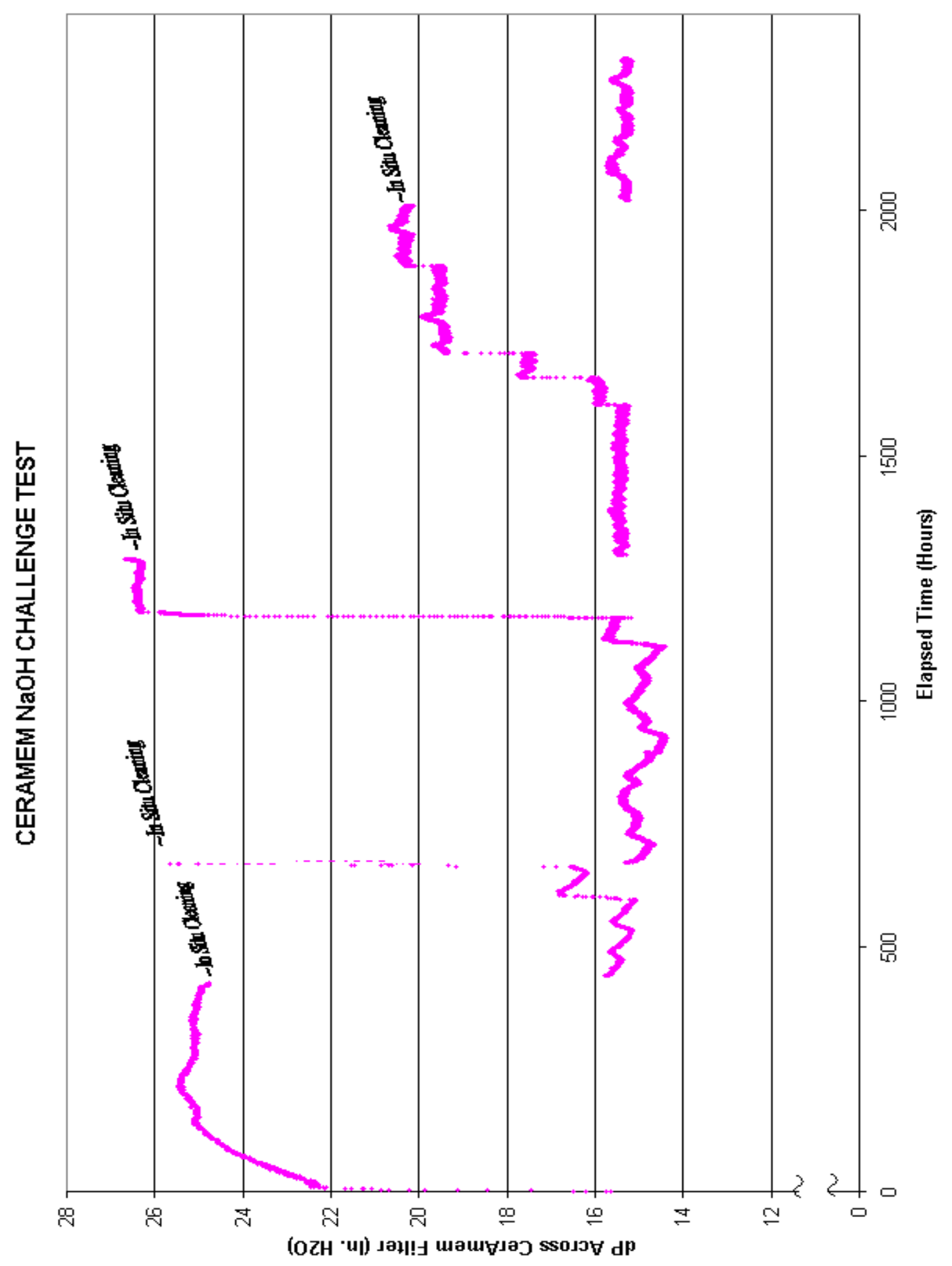

Curve 3 - Salt Solution, dP across CeraMem Filter 


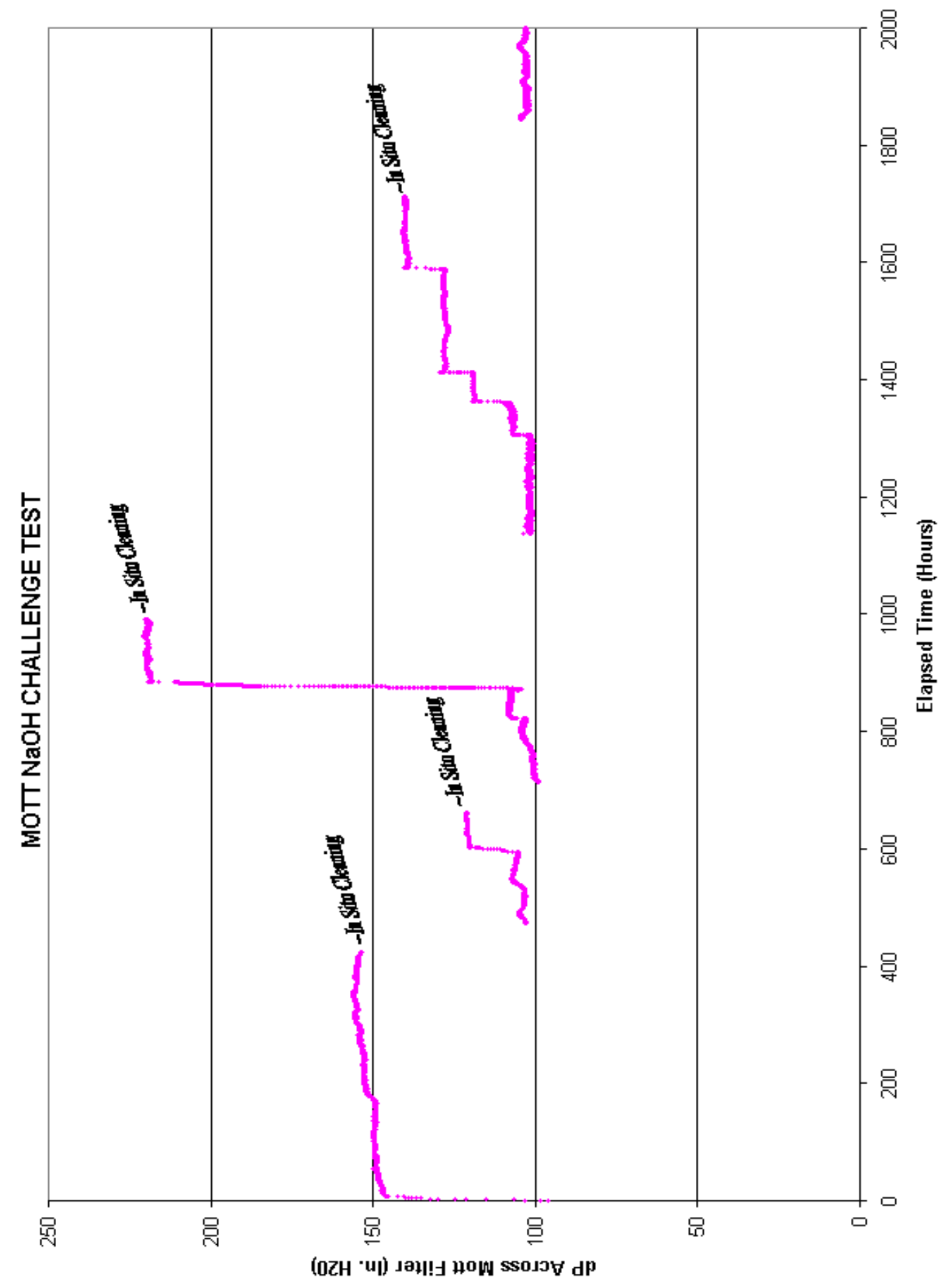

Curve 4 - Salt Solution, dP across Mott Filter 


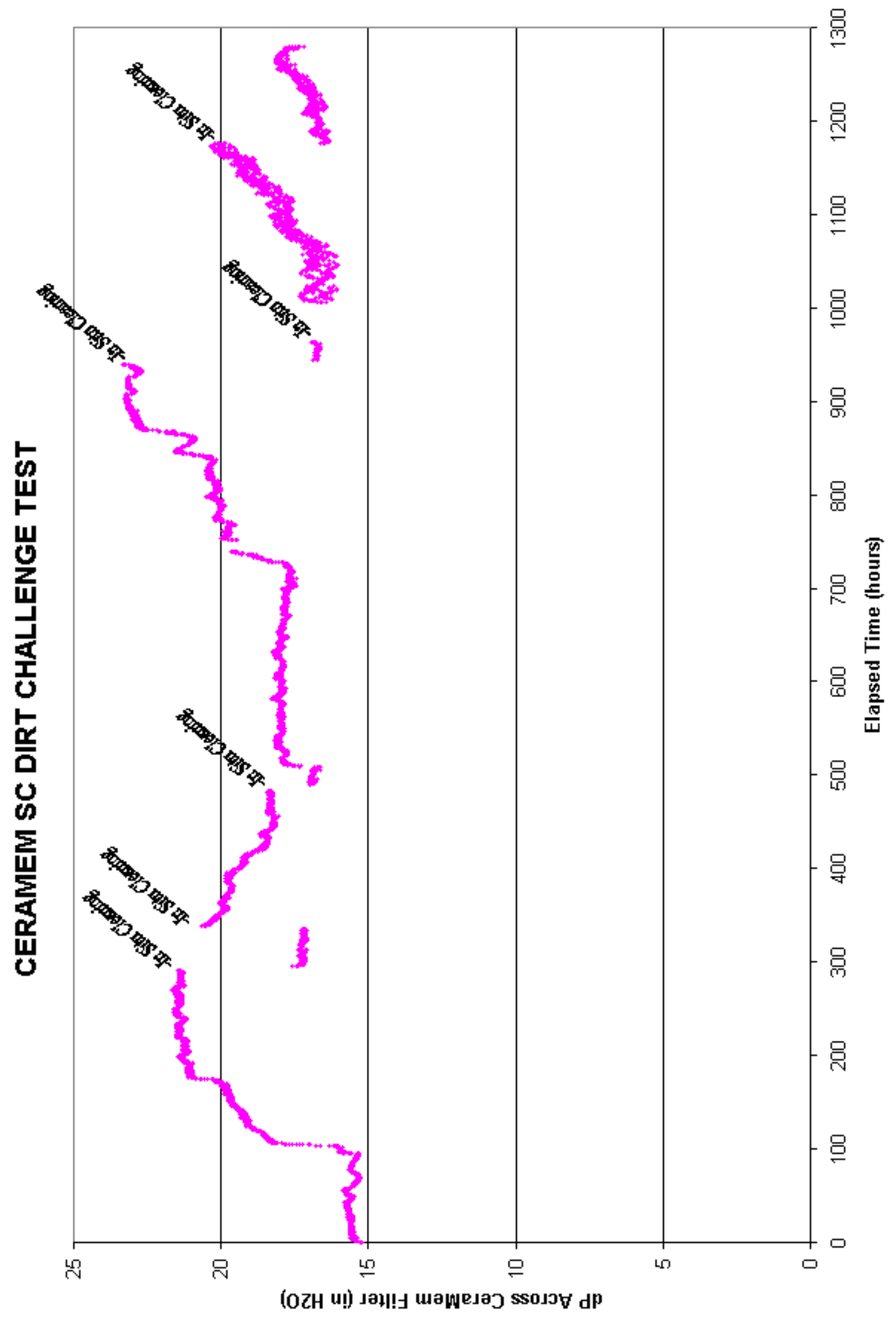

Curve 5 - SC Road Dust, dP across CeraMem Filter 


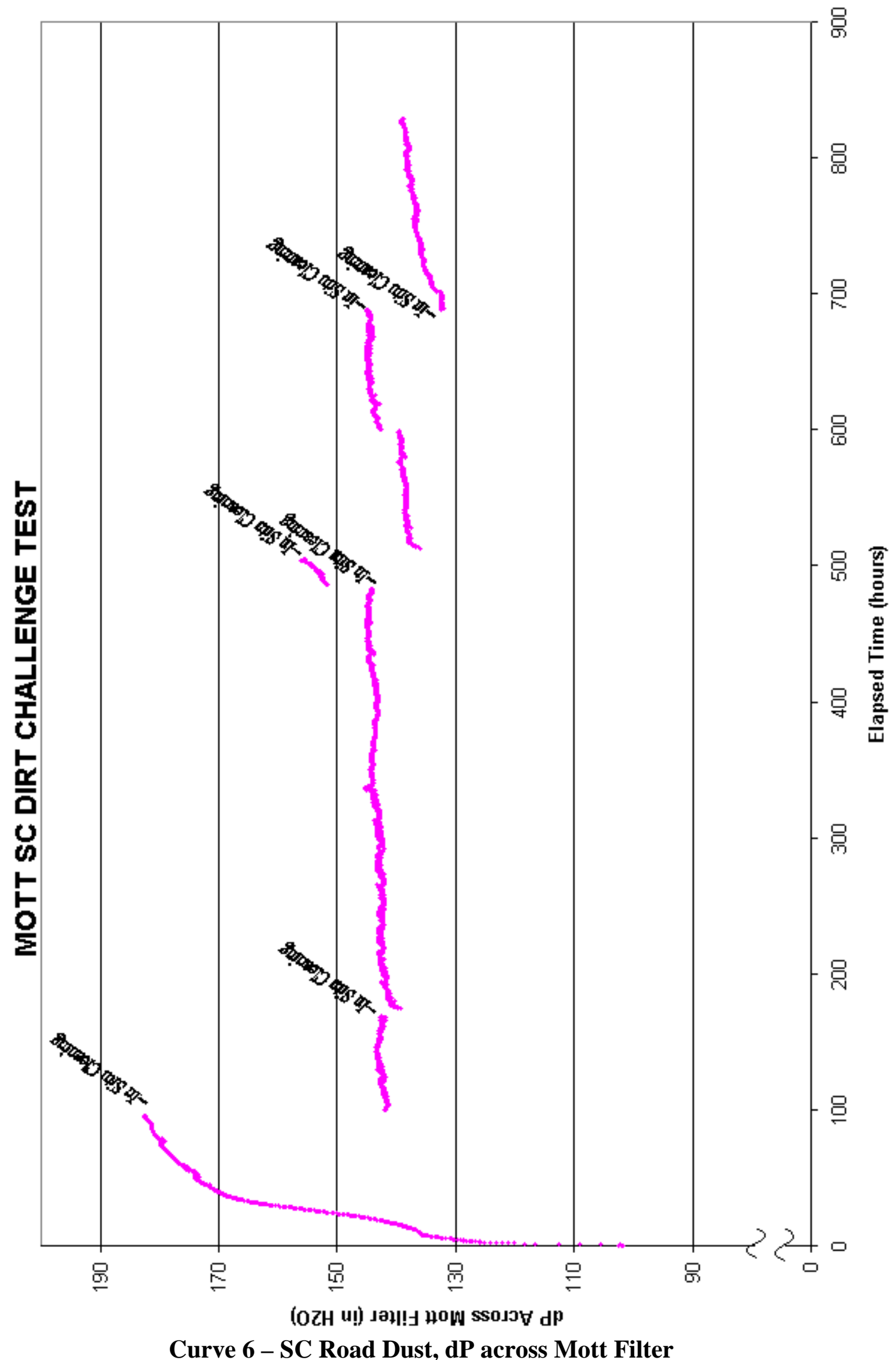

